\title{
ASUHAN KEBIDANAN Ny. V DENGAN LUKA EPISIOTOMI
}

\author{
Miratu Megasari, Iga Aulia \\ STIKes Hang Tuah Pekanbaru \\ miratu090586@htp.ac.id igaaulia18@gmail.com
}

\section{INTISARI}

Latar belakang studi kasus : Masa nifas atau puerperium adalah masa setelah persalinan selesai sampai 6 minggu atau 42 hari. Sekitar $60 \%$ kematian ibu terjadi setelah melahirkan yang didominasi oleh beberapa penyebab salah satunya infeksi dimana hal ini dapat dicegah dengan melakukan pertolongan persalinan yang bersih, deteksi dini infeksi, dan asuhan pada masa nifas yang baik. Ibu yang memiliki laserasi pada saluran genetalia termasuk episiotomi beresiko terkena infeksi pada masa nifas.

Tujuan studi kasus : Mampu melaksanakan asuhan kebidanan pada ibu nifas dengan perawatan luka episiotomi terhadap konsumsi ikan gabus untuk mempercepat pengeringan luka secara menyeluruh dan berkesinambungan.

Metode studi kasus : Metode yang digunakan adalah studi kasus, sedangkan metode pendokumentasian yang akan digunakan yaitu metode S-O-A-P. asuhan yang diberikan pada ibu nifas Ny.V dengan luka episiotomi terhadap konsumsi ikan gabus di PMB Hasna Dewi Kota Pekanbaru selama 10 hari dari tanggal 24 Agustus 2020 - 03 September 2020

Laporan kasus :ibu nifas Ny.v mengatakan ia merasa lelah dan nyeri pada daerah luka jahitan.

Simpulan : Asuhan kebidanan dilaksanakan menggunakan pendekatan dengan pendokumentasian SOAP (Subjektif, Objektif, Asessment, Penatalaksanaan).Tidak ditemukan kesenjangan pada hasil data subjektif dan objektif hasil dari mengkonsumsi ikan gabus selama 10 hari sebanyak 500 gram yang dikonsumsi perharinya didapat masa nifas Ny.V berjalan dengan normal, kondisi luka episiotomi bagian luar telah kering dan tidak ditemukan adanya tanda-tanda infeksi.

Saran : Diharapkan terus membimbing mahasiswa selama melakukan praktik di Klinik dan meningkatkan pelayanan menjadi lebih baik lagi, khususnya asuhan kebidanan pada ibu nifas untuk kunjungan ibu nifas di Klinik atau rumah bersalin terutama yang memiliki luka episiotomi sehigga dapat mendeteksi dini apabila terjadi infeksi atau masalah lain.

\section{Kata Kunci : Masa Nifas, Luka Episiotomi, Asuhan Kebidanan, Ikan Gabus}




\section{PENDAHULUAN}

Episiotomi ialah insisi perineum untuk memudahkan persalinan dan mencegah rupture perineum totalis, pada masa lalu dianjurkan untuk melakukan episiotomi secara rutin yang tujuannya untuk mencegah robekan berlebihan pada perineum. Membuat tepi luka rata agar mudah dilakukan penjahitan, mencegah penyulit atau tahanan pada kepala dan infeksi, akan tetapi hal itu tidak didukung oleh bukti-bukti ilmiah yang cukup. Sebaliknya, hal ini tidak boleh diartikan bahwa episiotomi tidak diperbolehkan, karena ada indikasi tertentu untuk tetap dilakukan tindakan episiotomi (Sulistyawati \& Nugraheny, 2010).

Episiotomi rutin tidak boleh dilakukan karena jumlah darah yang hilang meningkat dan risiko terjadinya hematom. Kejadian laserasi derajat tiga atau empat lebih banyak terjadi pada episiotomi rutin, meningkatkan nyeri pasca persalinan di daerah perineum, meningkatkan risiko infeksi pada multigravida dengan perineum yang kaku dan meningkatkan infeksi nifas jika tidak dirawat dengan benar (Afni et al., 2015).

Menurut (Maritalia, 2014), infeksi nifas adalah peradangan yang terjadi pada organ reproduksi yang disebabkan oleh masuknya mikroorganisme atau virus kedalam organ reproduksi tersebut selama proses persalinan dan masa nifas. Ibu yang mengalami infeksi nifas biasanya ditandai dengan demam (peningkatan suhu tubuh diatas $38^{\circ} \mathrm{C}$ ) yang terjadi selama dua hari berturut-turut. Adapun faktor predisposisi infeksi nifas diantaranya perdarahan, traumapersalinan, partus lama, retensio plasenta serta keadaan umum yang buruk mengenai anemia dan malnutrisi.

Proses penyembuhan luka dipengaruhi oleh pemenuhan nutrisi jika nutrisi seseorang tidak terpenuhi maka proses penyembuhan luka akan tidak baik dan membutuhkan waktu yang cukup lama. Hal ini terbukti dari hasil penelitian (Rahmawati \& Triatmaja, 2015) yang menyatakan bahwa terdapat hubungan pemenuhan zat gizi dengan pemulihan lukaperineum. Menurut penelitian yang dilakukan (Sakinah, 2017) menyatakan bahwa ada hubungan antara status gizi ibu nifas dengan penyembuhan luka perineum.

Nutrisi yang buruk akan menghambat proses penyembuhan bahkan menyebabkan infeksi pada luka. Nutrisi yang dibutuhkan dan penting adalah asam amino (protein), lemak, energi sel (karbohidrat), vitamin (C, A, B kompleks, D, K, E), zink, race element (besi, magnesium), dan air. Asam amino 
esensialdan non-esensial dapat ditemukan pada daging, ikan, dan putih telur (Arisanty, 2013).

\section{METODE STUDI KASUS}

Metode ini digunakan dalam bentuk pengkajian data subjektif, objektif, assesment dan penatalaksanaan. Metode ini menggali tentang bagaimana asuhan yang benar dalam penatalaksanaan dan pemeriksaan pada ibu nifas pada perawatan luka episiotomi dengan konsumsi ikan gabus.

\section{Lokasi dan Waktu}

\section{a. Lokasi}

Pengambilan kasus ini dilakukan di PMB Hasna Dewi Kota Pekanbaru yang beralamat di J1.HR Soebrantas Panam, Kec.Tampan

\section{b. Waktu}

Pengambilan kasus ini dilaksanakan pada tanggal 24 Agustus 2020 s/d 03 September 2020.

\section{HASIL STUDI KASUS}

1. Kunjungan Nifas Pertama di PMB Hasna Dewi Kota Pekanbaru (5 Jam Post Partum)

Tanggal 24 Agustus 2020

Pukul : 13.30 WIB

a) Pengkajian Data Subjektif
Ny.V berusia 18 tahun, agama islam, pendidikan terakhir SMA, pekerjaan ibu sebagai ibu rumah tangga, dan ibu beralamat di J1.Mayang Griya Asri II Ibu mengatakan ia merasa lelah dan nyeri pada daerah luka jahitan.

b) Pengkajian Data Objektif

Setelah melakukan pemeriksaan data objektif didapat hasil yaitu TD: 120/80 mmHg, N: $80 \times /$ i, P: 20 $\times / \mathrm{i}, \mathrm{S}: 36,55^{\circ} \mathrm{C}$, TFU 3 jari dibawah pusat, kontrasksi uterus baik, perdarahan $\pm 20 \mathrm{cc}$ berwarnah merah kehitaman (lochea rubra), luka episiotomi (mediolateralis), kondisi luka baik dan telah diberikan antiseptik setelah bersalin, pus (-), darah (-), odema (), infeksi perineum (-).

c) Assasment $\mathrm{P}_{1} \mathrm{~A}_{0} \mathrm{H}_{1}, 5$ jam post partum, K/U ibu baik dengan keluhan merasah lelah dan nyeri pada daerah luka jahitan.

d) Plan

1) Bina hubungan baik dengan ibu

2) Beritahu ibu hasil pemeriksaaan

3) Menjelaskan kepada ibu tentang keluhan yang ibu rasakan 
4) Menjelaskan pada ibu tentang pemenuhan nutrisi

5) Memberitahu ibu tanda-tanda bahaya nifas

6) Memberi ibu therapy obat Vit A

7) Memberitahu ibu kunjungan ulang

e) Implementasi

1) Membina hubungan baik dengan ibu

2) Memberitahu ibu hasil pemeriksaan saat ini bahwa keadaan ibu baik,TD: 120/80 mmHg, N: $80 \times / i, P: 20 \times / i, S:$ $36,5^{\circ} \mathrm{C}$, TFU 3 jari dibawah pusat, kontraksi uterus baik, perdarahan $\pm 20 \mathrm{cc}$ berwarnah merah kehitaman (lochea rubra), semua dalam keadaan yang normal.

3) Menjelaskan tentang keluhan ibu, nyeri pada luka jahitan yang ibu rasakan merupakan hal yang normal dirasakan selama proses penyembuhan luka. Dikarenakan sel-sel yang terputus akibat tindakan episiotomi membuat luka menjadi terasa nyeri, untuk membantu proses penyembuhan luka ibu membutuhkan asupan nutrisi yang cukup dan mengandung tinggi protein yang sangat bagus untuk proses penyembuhan luka Salah satu makanan yang mengandung tinggi protein yaitu ikan gabus. Untuk perawatan luka itu sendiri ibu dianjurkan untuk selalu menjaga kebersihan area luka, selalu mengganti pembalut jika sudah terasa penuh, membersihkan area vagina dari arah depan kearah belakang.

4) Menganjurkan ibu untuk menjaga pola makan, makanan yang beranekaragam mengandung karbohidrat, sayuran buahan serta lebih baik lagi juga mengkosumsi makanan yang tinggi protein karna dapat mempercepat penyembuhan luka. Contoh makanan yang mengandung tinggi protein yaitu salah satunya ikan gabus. Kebutuhan air minum ibu menyusui pada 6 bulan pertama yaitu sebanyak 14 gelas/hari, dan pada 6 bulan selanjutnya sebanyak 12 gelas/hari.

5) Memberitahu ibu tanda-tanda bahaya pada masa nifas yaitu perdarahan yang hebat, keluar cairan atau perdarahan yang berbau, demam tinggi, sakit kepala terus-menerus, penglihatan 
kabur, payudara bengkak hingga menyebabkan nyeri yang hebat dan ibu sampai demam.

6) Memberi ibu obat kapsul Vit A 2 butir (diminum 1 kali)

7) Menganjurkan ibu untuk kunjungan ulang jika ada keluhan.

\section{Kunjungan Nifas Kedua di Rumah}

\section{Pasien (5 hari post partum)}

Tanggal 29 Agustus 2020

Pukul : 13.50 WIB

a. Pengkajian Data Subjektif

Ibu mengatakan ASI nya lancar, lukanya masi terasa nyeri dan $\mathrm{BAB}$ sudah tidak sakit lagi.

b. Pengkajian Data Objektif

Setelah melakukan pemeriksaan data objektif didapat hasil keadan umum ibu baik yaitu TD: 120/70 mmHg, N: $82 \times /$ i, P: $22 \times / i, S$ : $36,6^{\circ} \mathrm{C}$, TFU pertengahan pusatsimpisis, kontraksi uterus baik, perdarahan $\pm 20 \mathrm{cc}$ berwarnah putih kemerahan (lochea sanginolenta), luka episiotomi (mediolateralis), kondisi luka baik, belum kering, pus (-), darah (-), odema (-), infeksi perineum (-).

c. Assesment

$\mathrm{P}_{1} \mathrm{~A}_{0} \mathrm{H}_{1}, 5$ hari post partum, K/U ibu baik dengan keluhan nyeri daerah luka jahitan. d. Plan

1) Memberitahu ibu hasil pemeriksaan

2) Mengevaluasi luka episiotomi

3) Menjelaskan tentang keluhan yang ibu rasakan

4) Memberi ibu sup ikan gabus

5) Memberitahu ibu cara perawatan luka.

6) Mengajarkan ibu teknik perawatan payudara.

7) Menjelaskan metode KB.

8) Memberitahu ibu kunjungan ulang.

e. Implementasi

1) Memberitahu ibu hasil pemeriksaan saat ini keadaan umum ibu baik TD: 120/70 mmHg, N: $82 \times /$ i, P: $22 \times /$ i, S: $36,6{ }^{\circ} \mathrm{C}$, TFU pertengahan pusatsimpisis, kontrasksi uterus baik, perdarahan $\pm 20 \mathrm{cc}$ berwarnah putih kemerahan (lochea sanguinolenta).

2) Mengevaluasi luka episiotomi dan pengeluaran pervaginam. (keadaan luka baik, pus (-), darah (-), tidak ada tanda-tanda infeksi, perdarahan \pm 20 cc yaitu lochea sanguinolenta, semua keadaan ibu dalam batas normal 
3) Menjelaskan keluhan yang dirasakan oleh ibu merupakan kondisi yang normal dan disebabkan oleh proses penyembuhan luka yang sedang berlangsung dan lama kelamaan akan hilang.

4) Memberikan ibu sup ikan gabus sebanyak 500 gram untuk proses penyembuhan luka episiotomi agar luka cepat kering dan mencegah terjadinya infeksi.

5) Mengingatkan ibu untuk tetap melakukan perawatan lukanya seperti tetap menjaga kebersihan diri terutama kebersihan daerah kemaluannya dan usahakan mengganti pembalut sesering mungkin.

6) Menjelaskan dan menganjurkan pada ibu untuk melakukan perawatan payudara.

7) Mengingatkan dan menjelaskan pada ibu untuk merencanakan metode KB yang akan ia gunakan sebelum masa nifas berakhir. Untuk KB jangka panjang ibu bisa menggunakan IUD atau IMPLAN, dan jika ingin menggunakan jangka pendek sebaiknya ibu menggunakan metode suntik 3 bulan agar tidak mengganggu kelancaran ASI, hal ini tergantung apakah ibu ingin membatasi jumlah anak atau menjarangkan kehamilan agar tidak terlalu rapat.

8) Memberitahu ibu untuk kunjungan ulang

3. Kunjungan Nifas Ketiga di Rumah Pasien (10 hari post partum)

Tanggal 03 September 2020

Pukul : 14.10 WIB

a. Pengkajian Data Subjektif

Ibu mengatakan bayinya semakin kuat menyusu dan ibu ingin memastikan apakah lukanya sudah sebuh atau belum. Ibu tidak memiliki keluhan lain.

b. Pengkajian Data Objektif

Setelah melakukan pemeriksaan data objektif didapatkan hasil yaitu saat ini keadaan umum ibu baik TD: 120/70 mmHg, N: 78 ×/i, P: 20 $\times /$ i, S: $36,3{ }^{\circ} \mathrm{C}$, TFU pertengahan pusat-simpisis, kontrasksi uterus baik, perdarahan $\pm 10 \mathrm{cc}$ berwarnah putih kemerahan (lochea sanguinolenta), luka episiotomi (mediolateralis), kondisi luka baik dan kering, pus (-), Infeksi perineum (-).

c. Assasment $\mathrm{P}_{1} \mathrm{~A}_{0} \mathrm{H}_{1} 10$ hari post partum, K/U ibu baik 
d. Plan

1) Memberitahu ibu hasil pemeriksaan

2) Mengevaluasi luka episiotomi

3) Menjelaskan pada ibu tentang personal hygiene

4) Memberitahu ibu tentang ASI eksklusif

5) Memberitahu ibu tentang nutrisi

6) Mengingatkan ibu untuk ber-KB

7) Mengingatkan ibu tanda-tanda bahaya nifas

8) Beritahu ibu untuk kunjungan ulang.

e. Implementasi

1) Memberitahu ibu hasil pemeriksaan saat ini keadaan umum ibu baik TD: 120/70 mmHg, N: $78 \times / \mathrm{i}, \mathrm{P}: 20 \times / \mathrm{i}, \mathrm{S}$ : $36,3{ }^{\circ} \mathrm{C}$, TFU pertengahan pusatsimpisis, kontraksi uterus baik, perdarahan $\pm 10 \mathrm{cc}$ berwarnah putih kemerahan (lochea sanguinolenta), luka episiotomi (mediolateralis), kondisi luka baik dan kering, pus (-), Infeksi perineum (-).

2) Mengevaluasi luka episiotomi dan pengeluaran pervaginam (keadaan luka baik dan sudah kering, pus (-), darah (-), tidak ada tanda-tanda infeksi, perdarahan $\pm 10 \mathrm{cc}$ yaitu lochea sanguinolenta).
3) Mengingatkan ibu untuk tetap menjaga kebersihan diri terutama kebersihan daerah kemaluannya dan ganti pembalut sesering mungkin.

4) Menganjurkan ibu untuk tetap memberikan ASI eksklusif kepada bayinya. Susukan bayi sesering mungkin minimal 2 jam sekali.

5) Menganjurkan ibu untuk tetap menjaga pola makan dengan gizi seimbang dan tinggi protein serta pola istirahat yang cukup.

6) Mengingatkan ibu untuk merencanakan metode $\mathrm{KB}$ yang akan ia gunakan sebeum masa nifas berakhir.

7) Mengingatkan ibu tanda-tanda bahaya masa nifas seperti yang sudah dijelaskan pada kunjungan sebelumnya

8) Menjelaskan dan mengingatkan pada ibu agar bayinya mendapatkan imunisasi yang lengkap. Imunisasi bayi selanjutnya yaitu saat bayi usianya satu bulan (imunisasi BCG di lengan dan polio yang di tetes dimulut. Sebaiknya ibu memeriksakan kondisinya ke fasilitas kesehatan terdekat jika ada keluhan 


\section{PEMBAHASAN}

1. Data subjektif

Data subjektif yang di temukan Ny. $\mathrm{V}$ mengatakan merasa lelah dan sedikit nyeri pada jahitan luka. Hal ini sesuai dengan teori yang dikemukakan oleh Wahyuni (2018) perubahan-perubahan fisiologis pada masa nifas dan menyusui mulai dari adaptasinya perubahan fisik, yaitu meliputi; perubahan sistem tubuh pada masa postpartum dan adaptasi pemenuhan kebutuhan fisiologis postpartum.

2. Data Objektif

Data Objektif yang didapat dari hasil pemeriksaan keadaan umum ibu baik TD: 120/70 mmHg, N: $82 \times /$ i, P: 22 $\times / \mathrm{i}, \quad \mathrm{S}: 36,6^{\circ} \mathrm{C}$, TFU pertengahan pusat-simpisis, kontrasksi uterus baik, perdarahan $\pm 20 \mathrm{cc}$ berwarnah putih kemerahan (lochea sanguinolenta), luka episiotomi (mediolateralis), kondisi luka baik, sudah kering dan sudah rapat. Data objektif yang ditemukan dari kunjungan pertama hingga kunjungan terakhir selaras dengan teori yang dikemukakan oleh (wahyuni, 2018) yang mengatakan bahwa perubahan-perubahan fisiologis pada masa nifas meliputi prubahan pada ukuran uterus yaitu terjadi penurunan bertahap sebesar 1 $\mathrm{cm} /$ hari di hari pertama uteri berada $12 \mathrm{~cm}$ di atas simfisis pubis dan pada hari ke-7 sekitar $5 \mathrm{~cm}$ di atas simfisis pubis dan pada hari ke-10 uterus hampir tidak dapat dipalpasi,perubahan tanda-tanda vital meliputi suhu tubuh normal adalah antara $36,5-37,5^{\circ} \mathrm{C}$ kenaikan suhu tubuh dapat mengindikasikan adanya tanda infeksi, denyut nadi normal adalah $60-80 x / m e n i t$ frekuensi nadi yang cepat dapat juga mengindikasikan terjadinya infeks, frekuensi pernapasan normal 12$16 x /$ menit di saat istirahat.Tekanan darah harus kembali ke batas normal dalam 24 jam setelah kelahiran waspada adanya kenaikan tekanan darah sebagai salah satu tanda preeklampsi/eklampsi untuk diingat bahwa preeklampsi/eklampsi dapat terjadi selama kehamilan, persalinan dan bahkan berlangsung hingga post partum. Perubahan pada penyembuhan luka perineum secara bertahap akan berkurang nyerinya dan penyembuhan trauma perineum biasanya terjadi dalam 7-10 hari postpartum.

3. Assessment

Assesment yang dapat di tegakan atau di simpulkan dalam kasus ini adalah Ny. V nifas hari ke 10 dengan luka episiotomi sudah kering dan 
rapat assesment yang ditemukan pada kunjungan terakhir selaras dengan penelitian yang dikemukakan oleh (Alauddin, 2016) yang mengatakan perbaikan luka sayat tercepat sebesar $99,21 \%$ pada hari ke-10.

4. Plan

Plan ( rencana ) yang diberikan pada kasus ini adalah beritahu ibu hasil pemeriksaan, menjelaskan kepada ibu tentang keluhannya, beritahu ibu cara perawatan luka, beritahu kepada ibu manfaat konsumsi ikan gabus untuk proses penyembuhan luka, minta persetujuan ibu, lakukan asuhan kepada ibu, jadwalkan kunjungan ulang plan pada kasus ini selaras dengan Megasari et al(2019).

\section{KESIMPULAN}

Setelah dilakukan asuhan kebidanan ibu nifas Ny.V di PMB Hasna Dewi Kota Pekanbaru pada bulan Agustus dengan perawatan luka episiotomi therapy konsumsi ikan gabus selama 10 hari sebanyak 500 gram yang harus dikonsumsi setiap harinya, kemudian penulis melakukan evaluasi dan dilakukan perbandingan atara teori dengan kasus yang ada, maka penulis mengambil kesimpulan tidak ada kesenjangan antara teori dengan kasus luka jahitan sudah sembuh dan sudah rapat pada hari ke sepuluh.

\section{SARAN}

1. Bagi PMB Hasna Dewi

Diharapkan terus membimbing mahasiswa selama melakukan praktik di Klinik dan meningkatkan pelayanan menjadi lebih baik lagi, khususnya asuhan kebidanan pada ibu nifas, seperti:

a) Meningkatkan jumlah kunjungan ibu nifas di Klinik atau rumah bersalin terutama yang memiliki luka episiotomi sehigga dapat mendeteksi dini apabila terjadi infeksi atau masalah lain.

b) Melakukan penyuluhan tentang ibu nifas terutama tanda bahaya dan resiko terkena infeksi selama masa nifas.

c) Dapat memberikan konseling, melakukan asuhan terutama perawatan luka episiotomi dengan menggunakan evidence based yang selalu up to date

2. Bagi Instansi Pendidikan STIKes Hang Tuah Pekanbaru

Diharapkan studi kasus yang telah dilakukan dapat menambah sumber wawasan pengetahuan mahasiswa, khususnya DIII Kebidanan STIKes Hang Tuah Pekanbaru serta dijadikan referensi sebagai pengembangan ilmu 
pengetahuan tentang asuhan kebidanan pada ibu nifas dan sebagai pedoman untuk pengambilan studi kasus berikutnya.

3. Bagi Penulis

Diharapkan agar dapat menambah pengetahuan serta keterampilan melalui pengalaman yang telah didapat dalam memberikan asuhan kebidanan pada ibu nifas yang sesuai dengan Kepmenkes Indonesia No.1464/Menkes/Per/X/2010tentang izin dan penyelenggaraan praktik bidan.

\section{DAFTAR PUSTAKA}

Afni, R., \& dkk. (2015). Buku Ajar Asuhan pada Ibu Bersalin. Yogyakarta: Budi Utama.

Alauddin, A. (2016). Uji Efek Ekstrak Ikan Gabus (Chana Striata) pada Luka Sayat dengan Tikus Putih Jantan Galur Wisatar Yang Diberikan Secara Oral. [Skripsi], Universitas Tanjungpura Pontianak 2016.

Arisanty, IP. (2013). Manajemen

Perawatan Luka. Jakarta: EGC.

Asfar, M., Bakar Tawali, A., \& Mahendradatta, M. (2014). Potensi Ikan Gabus ( Channa Striata ) Sebagai Sumber Makanan Kesehatan (Review).
Fitriana, Y., \& Nurwiandani, W. (2018). Asuhan Persalinan Konsep Persalinan Secara Komprehensif dalam Asuhan Kebidanan. Yogyakarta: Pustaka Baru Press.

Intiyani, R., Astuti, D. P., \& Sofiana, J. (2018). Pemberian Suplemen ASI Zinc dan Ekstrak Ikan Gabus Untuk Mempercepat Penyembuhan Luka Perineum. Jurnal STIKes Muhammadiyah Purwokerto 2018, Purwokerto.

Karina, N., Wagiyo, \& Elisa. (2016). Efek Pemberian Ekstrak Ikan Gabus Terhadap Penyembuhan Luka Perineum Pada Ibu Post Partum Di Bpm Bonangrejo Demak.Jurnal Ilmu Keperawatan Dan Kebidanan (JIKK).

Kusmini, I. I., Gustiano, R., Prakoso, V. A., \& Ath-thar, M. F. (2016). Budidaya Ikan. Bogor: Penebar Swadaya.

Kuswanti, I., \& Melina, F. (2014). Askeb II Persalinan. Yogyakarta: Pustaka Pelajar.

Maritalia, D. (2014). Asuhan Kebidanan Nifas dan Menyusui. Yogyakarta: Pustaka Baru Press.

Megasari, M., \& dkk. (2019). Catatan SOAP Sebagai Dokumentasi Legal dalam Praktik Kebidanan. Yogyakarta: Nuha Medika. 
Rahmawati, E., \& Triatmaja, N. T. (2015). Hubungan Pemenuhan Gizi Ibu Nifas Dengan Pemulihan Luka Perineum.Jurnal Wiyata, Vol. 2 No.1, Juni2015, Surabaya.

Sakinah, T. P. (2017). Hubungan Status Gizi Ibu Nifas dan Budaya Makanan Pantangan Masa Nifas dengan Penyembuhan Luka Perineum Di RS
Dewi Sartika Kota Kendari. [Skripsi], Juli 2017, Kedari.

Sudarti, \& Fauziah, A. (2011). Buku Ajar Dokumentasi Kebidanan. Nuha Medika.

Sulistyawati, A., \& Nugraheny, E. (2010). Asuhan Kebidanan pada Ibu Bersalin. Jakarta: Salemba Medika. 